\title{
Titel/Title: Small Country, Big Business? New Zealand As Education Exporter
}

Autor*innen/Author(s): Kerstin Martens

Peter Starke

Veröffentlichungsversion/Published version: Postprint

Zeitschriftenartikel/Journal article

\section{Empfohlene Zitierung/Recommended citation:}

Martens, Kerstin/ Starke, Peter (2008): Small Country, Big Business? New Zealand as an Education Exporter. In: Comparative Education, 44 (1), 3-19.

Verfügbar unter/Available at:

(wenn vorhanden, bitte den DOI angeben/please provide the DOI if available)

This is an Accepted Manuscript of an article published by Taylor \& Francis in Comparative Education on 17.08.2009, available online: https://doi.org/10.1080/03050060701809367

Zusätzliche Informationen/Additional information:

The author can be contacted at: martensk@uni-bremen.de 
Kerstin Martens and Peter Starke

This paper discusses New Zealand's role in the global market for tertiary education. The internationalisation and liberalisation of education markets is progressing rapidly in today's globalising world, as reflected by the incorporation of education as a service into the GATS framework. Through the example of New Zealand as a case study for the internationalisation of education services, the study depicts the way the government is involved in this process. Commodification of sectors traditionally subject to domestic public policy is often associated with a less interventionist state, but our example of education shows that this is not necessarily the case, at least not in the medium-term: New Zealand's government rather appears to be an active facilitator of the liberalisation process in education. We review its recent move towards treating education as an international export good and present data on the growth of this industry. The paper concentrates on the particular ways by which New Zealand's government is trying to facilitate this process of liberalising the education sector.

\section{INTRODUCTION - EDUCATION AS AN EXPORT INDUSTRY OF NEW ZEALAND $^{1}$}

What are the main export goods of New Zealand? Intuitively, one thinks of lamb, wool, kiwi fruit, and maybe apples. In recent years, however, another sector has become a major export business for New Zealand: education services today rank fourth in service exports and fifteenth in terms of export as a whole (OECD 2004). In 2003/2004, these exports made up NZ $\$ 1.4$ billion, $12.8 \%$ of the country's overall service exports (Statistics New Zealand 2004). Export of education generates more foreign exchange for New Zealand than its wine industry (e.g. Ministry of Education 2001a: 5). The aim of this paper is to explore the extent of education as an export good for New Zealand. The focus is put on the quantitative dimensions of education export, its growth over the last years, as well as the underlying conditions which enable such growth: political incentives and international

\footnotetext{
${ }^{1}$ This article is the result of cooperation between two projects of the Collaborative Research Centre "Transformations of the State" at the University of Bremen (http://www.state.uni-bremen.de). Project C4 deals with the Internationalisation of Education Policy by examining international organisations involved in education policy and by assessing the dimensions of the international education market. Project C1 examines Social Policy in Small Open Economies, and deals with New Zealand's policies within a comparative framework. We wish to thank Roger Dale and Achim Hurrelmann for encouraging and valuable comments on an earlier version of this article. For assistance in the preparation of this article we would like to thank Lisa Zelljadt, Celia Enders, Jegapradepan Arumugarajah and Rainer Stanke.
} 
developments.

Historically, education is seen as a public good based on ideals of egalitarianism and social welfare. Public education was meant to contribute directly to building communities of literate and informed citizens. In recent years, steps towards a greater commercialisation of educational policy can be observed. With increasing economic pressure on the welfare state and the rise of neo-liberal concepts, education policy has been subsumed to a large extent under economic policy. This trend has been accelerated under the influences of globalisation and the rise of the new knowledge-based economy (OECD 2001; Kahin \& Foray 2006; Peters 2006). Education has progressively been discovered as a lucrative service industry and export commodity, and governments of industrialised countries have actively sought to take advantage of a growing national and international market. $(\leftarrow$ p. 3$)$

We focus on New Zealand as a case study because it is today one of the countries most active in pushing the concept of education as a business sector. We thus also fill a gap in the increasing research on educational markets, as most existing studies on that subject focus on the US market, which is by far the largest and attracts many foreign students (see for example, Levin 2001; Bok 2003; Hentschke \& Tierney 2005). In the Asian Pacific Area, Australia traditionally receives the most attention in this field, as well as the most foreign students (Harman 2004). The extent of the New Zealand education industry, instead, has been examined only rarely (see Taylor 2000; Lewis 2005), despite its particular interest in education export and its driving position in fostering the international liberalisation of this sector.

In this paper we show that the New Zealand government in fact spearheaded policy by pushing education as an export product. Internationalisation of education is often interpreted as undermining state autonomy by creating new modes of governance and a transnational market only marginally affected by state intervention (van der Wende 2001; Enders 2004). Thus, by examining the field of education policy, traditionally seen as a bastion of the nation-state, we also address the fate of the "intervention state" (see Zürn \& Leibfried 2005) in the era of globalisation in a particular policy field ${ }^{2}$. The case of New Zealand is thus explored in the light of the broader discussion about the changing role of the state in public services. Does internationalisation in education lead to less state intervention? Is the state's role redefined by this process? To what extent is internationalisation of the education sector inevitable for national governments, or, on the contrary, even fostered by them?

\footnotetext{
2 The term "intervention state" refers to modern states (in the OECD world) which, since the late nineteenth century, have taken responsibility for the well-being of their citizens and intervened into societal, especially market, relationships in order to achieve redistributive ends and to promote economic growth, full employment and other goals. Intervention state is meant to comprise not only the "welfare state" (social security, education, etc.) but, more generally, also economic "market-making" regulations and the provision of infrastructure by the state (see Zürn \& Leibfried 2005: 9-10).
} 
The paper is structured as follows: the first section presents general observations about the recent development in the education sector to put the developments in New Zealand in perspective. We explore recent trends in education as an export, focusing on tertiary or post-secondary education because the significance of export education, e.g. in terms of student numbers, is particularly evident at this level ${ }^{3}$. The international context and its influence on the growing liberalisation of education services under the General Agreement on Trade in Services (GATS) agreements are important here as 1 January 2005 marked the deadline for negotiation proposals on services. The second part of the paper explores New Zealand's education export in detail, presenting figures about the size and growth of the education sector as an export industry, and examining the government's role in the process. The conclusion relates our findings regarding export education to the debate about the "intervention state" and we discuss to what extent greater liberalisation leads to a diminished or a more active role for the state.

\section{INTERNATIONALISATION AND COMMERCIALISATION PROCESSES IN THE EDUCATION SECTOR}

Neo-liberalism has been a driving and powerful paradigm in the formation of public policies - including education - from the 1980s onwards in many countries. Conceptualisations such as the "knowledge economy" and the "knowledge society" have led to a shift in focus away from citizenship as the primary purpose of education towards the full commercialisation and commodification of education. This trend has been accelerated by governments which embraced economic globalisation, human capital theory, transaction cost models and other laissez-faire conceptualisations of the economic sphere seeking to create the appropriate conditions, laws and institutions necessary for a full-fledged market (Olssen 2001: ch. 2). The promotion of free trade not only in material goods, resources and other commodities but also in services such as education has become a major issue in recent years. Policy reforms in many countries aim directly at benefiting the national economic growth - under the assumption that international trade opens up opportunities in education export and in the creation of local employment. Especially through the negotiations of the GATS, education is increasingly becoming a field of international commerce with a growing number of internationally operating service providers. $(\leftarrow$ p. 4$)$

\section{TWO LOGICS OF INTERNATIONALISATION IN THE FIELD OF EDUCA- TION}

\footnotetext{
${ }^{3}$ We follow the widely recognised OECD definition of post-secondary education, whereby "postsecondary education covers courses leading to higher qualifications other than those awarded at the end of secondary schooling. ... [P]ost-secondary education covers post-secondary non-tertiary education... the first stage of tertiary education ... leading to pre-degree and advanced vocational qualifications; and the second stage of tertiary education leading to advanced research qualifications". It also covers adult education programmes that award credits at the tertiary and post-secondary level (see OECD 2004: 37).
} 
Over the last two decades, education has increasingly evolved not only into an internationalised policy field but also into an internationally traded commodity. Various trends can be observed which have fostered such developments. Larger numbers of students are willing to study abroad and decide to do parts of or even an entire degree programme at a foreign university. A greater number of exchange programmes now give students more flexibility in the design of their credit distribution, and thus enable them to study abroad more easily. Less expensive air fares also make going abroad more affordable for students than ever before. At the same time, providers of education services, such as universities, private language schools, or training institutions, are increasingly setting up business in countries other than their country of origin by establishing new branches or partner institutions, and by selling their educational services to foreign students who remain in their home country. Similarly, new communication technology allows universities to operate abroad with ease and teach students anywhere over the internet. Distance learning programmes enable students to participate in courses of foreign universities while staying at home. Students have access to comprehensive information about the choice of courses, institutions and living conditions in foreign countries. The internet also facilitates international student mobility as it allows keeping in touch with family and friends at home at low cost.

From an analytic point of view, there are today two distinct - but not necessarily mutually exclusive - logics which drive this internationalisation in education: a culture-driven approach and a trade-driven approach. Educational exchange as such is not new - it has existed for centuries. In Europe, the history of internationalised higher education goes back to the Middle Ages when "wandering students" went across the continent to study at different centres of learning. However, such cross-border activities in the field of education were mainly confined to one type of activity, namely student mobility. Recently, not only has the number of mobile students dramatically increased, but institutions and programmes also "go abroad": international programmes are no longer restricted to attracting foreign students - instead, they themselves cross borders to where their potential clients are. Academia has become increasingly transnational in both consumption and provision (OECD 2004: 18). As a consequence, education has also increasingly become an export industry.

There are several reasons for this trend. Traditionally, students studied abroad mainly to acquire cultural and language skills. Students perceived a stay at a foreign university mainly in terms of gaining so-called "soft skills": experiencing a different country, improving language ability, living out cultural diplomacy, etc. Today, however, students increasingly view studying abroad not only as a cultural experience, but as a means for high-ranking qualifications (or at least higher ranking qualifications than those offered by domestic institutions) and subsequently 
better access to a wider job market. Moreover, political incentives, especially on the regional level, such as the ERASMUS and SOCRATES exchange programmes in Europe, make it easier for students to go abroad temporarily and have their studies recognised in their home country upon return.

At the same time, higher education has shifted from elite to mass education in many countries, especially since the 1980s. More and more students seek to go to universities and receive degrees (BA, MA) before entering the work force. However, increasing economic constraints make it difficult for public universities to meet expectations. Governments put pressure on universities to create maximum output with their allocated financial inputs, while international organisations such as the World Bank and the Organisation for Economic Co-operation and Development (OECD) promote the idea that education should serve economic purposes. Domestic institutions are often unable to meet the growing demand for education and tertiary courses. Particularly in the developing world and newly developed countries, the number and range of services offered $(\leftarrow \mathbf{p .} \mathbf{5})$ by universities and colleges is often insufficient. This has opened up opportunities for countries that $d o$ have strong education capabilities to serve more students than their own domestic population.

Thus, for a long time, the "culture-driven" approach was the driving force for internationalisation processes in education. It is based on the idea that student exchange is beneficial for both the home country and the host country of the student in question in terms of sharing cultural, social and political values. In recent years, this perspective has been complemented by a "trade-driven" conceptualisation of educational services, by which internationalisation of education focuses on supporting the export of educational services for economic benefits (OECD 2004). A trade-driven strategy is characterised by higher levels of tuition for foreign students, institutional marketing to attract students, and the delivery of education services to students who stay in their home countries instead of going abroad. Against this background, students are increasingly regarded as clients or customers, particularly at institutions of higher education. Most importantly, international students have become a source of revenue as potential buyers of the product education.

Such developments may also change the role of the state in education policy. While governance in education has conventionally been performed hierarchically by the national state or government, especially in terms of the provision of services, financing, and standard-setting, today, market rules increasingly penetrate domestic education systems promoting an economically driven worldwide competition for students, research and consultancy. Such developments towards commodification result in an internationalisation of education markets, and often also in the privatisation of education providers and goods. Here, the role of 
governments may become one of a regulator of education policy rather than a provider. Moreover, such increasing marketisation of education may promote education as a private good.

\section{THE ROLE OF GOVERNMENTS IN THE INTERNATIONALISATION AND COMMERCIALISATION OF EDUCATION}

Governments have provided the institutional and regulatory frameworks for the internationalisation of education, for example by offering financial incentives to study at a foreign university. International organisations often assist this effort by allowing internationalised courses of study. Through common programmes, international organisations allow for an easy flow across member state borders. Particularly in the European region, the cultural approach is strongly politically motivated. In fact, with the ongoing Bologna process, EU countries aim at establishing a common European zone in which students can move with ease from one country to another and have their previous studies recognised in any signatory country university (Corbett 2003; Martens et al. 2004; Wächter 2004). However, governments not only actively support student and teacher mobility for cultural and political reasons; they also set up incentives for trade-driven reasons, for example; through favourable taxation rates for universities. More specifically, governments assist their universities and colleges in getting more foreign students into the country by summarising relevant information for prospective students and facilitating visa procedures.

Political incentives for the development of international education have themselves become international. The General Agreement on Trade in Services (GATS) allows for a liberalisation of the service sector to which education belongs. GATS is modelled after the General Agreement on Tariffs and Trade (GATT)/World Trade Organisation (WTO) trade agreement, and is likewise a multilateral and legally enforceable agreement governing trade between the signatory countries. Just like GATT, it offers liberalised trade by mutually agreed rules, binding market access, and non-discriminatory commitments. It came into force in 1995, is administered by the WTO, and reflects the growing importance of services in international trade. Such liberalisation agreements are a driving force for the internationalisation of educational services. Similar behaviour takes $(\leftarrow \mathbf{p .} \mathbf{6})$ place outside GATS or predates it, but GATS accelerated these activities. GATS thus provides the political and legal framework for deregulation and privatisation of education, which makes it possible to regard education as an internationally tradable commodity.

GATS also furthered international debates on the potentials and perils of educational markets. Critics argue that already existing inequalities between both individuals and countries are likely to become more severe, and that, furthermore, 
deregulation will, in the long run, privilege private owners of educational services and as such secure the power of capital. In contrast to these critics, others expect a gain in efficiency of educational services through stronger privatisation. Market optimists believe that the self-regulating mechanism of supply and demand will lead to an increase in efficiency, since only high-quality education products will survive in a consumer market. Coming along with marketisation is thus a gain in quality, which is argued to enhance both the educational outcomes of individuals as well as a country's competitiveness on the world market (for an overview, see Scherrer 2007).

To date, 25 OECD countries and 28 other WTO members have made commitments for at least one education sub-sector. New Zealand is one of four countries - next to Australia, Japan, and the US - that have tabled proposals for further liberalisation of trade in educational services, stressing the need for expansion of higher education and adult education or training, particularly through use of the internet: "In addition to generating revenue for private and state sector education institutions, and Members' economies, trade in education services provides benefits to participating economies at the individual, institutional and societal level, through academic exchange, increased cross-cultural linkages and technology transfer. Increased access for Members to education where it has previously been limited is a vital component in the development of human capital (World Trade Organisation Doc. S/CSS/ W/93: §2)".

The majority of the liberalisation in the GATS context is in higher and adult education, whereas primary and secondary educational services are treated as off-limits. On the whole, "they [governments] have maintained slightly more limitations on primary than on secondary, higher or adult education, and have been more sensitive about foreign institutions, companies and professionals operating in their countries ... than about cross-border supply ... or students travelling abroad (OECD 2002: 107)".

For the GATS, education as an export good refers to situations where teachers, students, programmes, institutions, or course material cross national borders. Since course attendance involves fees, education constitutes a business industry. In addition, the internationalisation of education carries with it potential growth in other economic sectors: when people or institutions go abroad for educational services, they have travel expenses, education costs, and living expenses, often directly financed by the individual student and his or her family. Although some of these costs are met by grants and subsidies from governments, education export is thus an important source of export revenue in some OECD countries.

\section{THE GATS CONCEPTUALISATION OF EDUCATION AS AN EXPORT GOOD AND ITS CONSEQUENCES}


The GATS identifies four modes of cross-border liberalisation of services in Article I (WTO 2000):

- Mode 1 concerns the supply of services abroad, corresponding with "normal" cross-border trade in goods. It is a straightforward form of trade in services because it resembles the familiar exchange between a seller and a buyer in which only the service itself crosses national frontiers. In the field of education this refers to e.g. distance learning programmes.

- Mode 2 concerns the consumption of services abroad, referring to situations where a consumer moves into another territory to obtain a service, for example, for tourism or to $(\leftarrow \mathbf{p}$. $\mathbf{7})$ visit a doctor while abroad. In the field of education, this may include attending an educational establishment like a language school or degree programme at a foreign university. Consumption abroad presents the largest component of international trade in education.

- Mode 3 refers to the supply of a service through the commercial presence of the foreign supplier in another country. This mode of delivery is often called "offshore provision". It implies that a supplier from one state establishes a territorial presence (including ownership or lease of premise) in another member's territory to provide a service. Branch offices or agencies to deliver banking, legal advice, or communication services fall under this mode. In the field of education, it refers to universities operating abroad to meet the demand of students who do not want to or are unable to study overseas. Such services are attractive to students because of lower costs. This mode is growing in importance.

- Mode 4 involves natural persons providing services abroad. In other words, it concerns the admission of foreigners to another country to provide services there. This mode is often found in combination with mode 3 because a visiting person may be an employee of a foreign service supplier, but someone can also provide a service as an independent person. In the field of education, this involves, for example, teachers who teach at a foreign university or other mode 3 institutions.

Thus, the context of education is changing with increased globalisation. Traditional reasons to internationalise education are shifting in the eyes of both governments and the public, from the perceived benefits of intercultural exchange to perceived benefits of profitable trade. Education, like many other inherently value-laden and culture-specific societal issues that were previously considered immeasurable in economic terms, is becoming commodified. This is evidenced not only by the actions of students and teachers, who increasingly see themselves as producers and consumers, respectively, of the "good" education, but also in the actions of international institutions. As illustrated by the GATS definitions explained above, the most significant agreement affecting the global economy has incorporated education into the realm of services subject to trade regulations, 
categorisations, and stipulations. The resulting increasingly universal understanding of education as a tradable good affects the way national governments treat their domestic education programmes and policies.

The recognition of new qualifications, the registration, quality assurance and accreditation of new types of providers, as well the financing of education, require state action as far as regulation is concerned. The marketisation of education also challenges the state's dominant role in this policy field because it raises the question to what extent domestic and international market actors increasingly privatise the provision of what used to be public educational services. Thus, for the establishment of an educational market as regards providers, students and goods, and for the prevention of market failure, the role of governments in education policymaking will be reassessed. Moreover, market elements enhance the role of governments in terms of accreditation of institutions and programmes, quality assessment and the provision of information, and revitalise discussions about equity and externalities, and the social costs and benefits of education in general. The following section discusses how one particular nation has dealt with that changing role of education: New Zealand.

\section{NEW ZEALAND AS A PROVIDER OF EXPORT EDUCATION}

For decades, New Zealand's only official exchange programme was the so-called "Colombo Plan", under an agreement of the Commonwealth. It started in March 1951 with the formal acceptance of six students from Ceylon (now Sri Lanka) to be trained in New Zealand as dental nurses (Oettli 1999). The Colombo plan was part of New Zealand's foreign aid policy, deliberately directed towards the poorer countries of Asia $\left(\right.$ Butcher 2003) ${ }^{4}$. The commercialisation of New $(\leftarrow \mathbf{p}$. 8) Zealand education by pushing it onto the international education market, instead, started in the mid-1980s when the Labour government's reforms aimed at refocusing educational goals inspired by neo-liberal theories. This set the agenda for commercialising and internationalising education policy in New Zealand.

\section{LABOUR GOVERNMENT AND THE NEO-LIBERAL SHIFT IN EDUCA- TION}

Following the election of the fourth Labour government in July 1984, neo-liberal reforms significantly changed the country's perception of education policy. The period is famous for Rogernomics - named after Minister of Finance Roger Douglas - which was perhaps the most comprehensive economic liberalisation programme a western country has ever experienced. At this time, the Treasury

\footnotetext{
${ }^{4}$ For a detailed historical account of the development of international students in New Zealand since 1950 in general and under the Colombo Plan in particular, see Tarling (2004).
} 
in particular became a powerful institution influencing state policy- making, including education policy, by pushing an agenda based upon human capital theory, public choice theory and transaction cost economics (Fitzsimons et al. 1999; Olssen 2001; Codd 2003). From a neo-liberal perspective, the economy became the primary source of legitimising the role of the New Zealand state in education. In Treasury documents, such as the 1987 Government Management report on the role of the state in the economy, it was argued that education should no longer be seen as an investment by the government in the wealth-generating capacity of the nation as such, but instead as a drain on the nation's resources: because it is keeping taxation high, is stifling investment and is providing benefits mainly to the individual who receives it - rather than the nation as a whole - education is costly to society instead of providing revenue (Codd 2003: 24).

From the mid-1980s onwards education policy in New Zealand has strongly been influenced by such a view: under the influence of neo-liberalism, the central focus of education policy shifted from citizenship to the national economy and the role of education institutions as "enterprises". The focus of education became redefined within the context of international economic competitiveness. In New Zealand education reforms, these concepts have been enormously influential in shaping education policy in general. It also specifically changed the perception of education aims: the purpose of commercialisation is not only to improve educational efficiency in the utilisation of resources, but to change the very nature of education from a public to an economic good.

This redefinition of education as a commodified market became also translated into making education an export good. Inspired by Australia's shift from "aid" to "trade" in 1987 (Alvey et al. 1999; on Australia, see Harman 2004), the New Zealand Market Development Board(NZMDB) recommended that educational institutions should compete for tuition-paying foreign students, a practice which had until then been prohibited. The Labour government, which had already opened up other sectors (e.g., manufacturing) to international competition, welcomed this call and soon prepared legislation for the liberalisation of education as an export good. In 1989, the Education Amendment Act cleared the way towards a policy of charging foreign students the full cost of their studies. Three conditions were attached to this authorisation, emphasising the economics of education services: (1) international students should only be enrolled where they do not displace local students; (2) international students are charged full cost for the provisions of educational services in New Zealand (Alvey et al. 1999: 4); (3) full cost is equal to course tuition plus relevant overhead costs per student.

From the 1990s onwards, the marketing of New Zealand education then became more professionalised and institutionalised. Education services were first promoted by New Zealand International Education (NZIEL), a business enterprise 
which marketed New Zealand "made" education internationally (Butcher 2003). It was later renamed Education New Zealand. In 2000, after a decade of rapid growth, the export education industry was officially acknowledged by the Government when Tourism New Zealand and Trade New Zealand entered into a partnership $(\leftarrow \mathbf{p . ~ 9})$ with Education New Zealand to form the New Zealand International Education Marketing Network. Its purpose was to develop and distribute the New-Zealand-wide brand and marketing of education services (Codd 2003).

Whereas the country's participation in internationalisation of education had traditionally been limited, it now pushed towards opening up the New Zealand educational institutions for the international market. Until the mid-1980s New Zealand had no policy on the internationalisation of New Zealand education, let alone of foreign fee-paying students or education as an export industry (Butcher 2003). Only with the introduction of the economic paradigm into the education sector did the country start to seek foreign students as a source of increasing revenues. In the following years, New Zealand saw a remarkable growth in the export of education. The sector became a major industry with attendant revenues, particularly in terms of student mobility.

\section{FOREIGN STUDENTS IN NEW ZEALAND}

Since this opening of the education sector to foreign students by the New Zealand government, the sector has developed remarkably. Whereas in the past, profitability did not play a role in education policy, the overwhelming majority of foreign students today pay tuition ${ }^{5}$. This is true not only at public tertiary institutions such as universities, polytechnic institutes, colleges, and wananga (Maori education providers), but also in the primary and secondary sector. Furthermore, private English language schools have received a growing number of students. Education sector data for New Zealand show these remarkable changes ${ }^{6}$.

\footnotetext{
${ }^{5}$ However, the "aid" approach, i.e. cooperation with developing countries in the field of education, continues parallel to the export education strategy through a range of bilateral scholarship programmes such as the Commonwealth Scholarship or the Aotearoa Scholarship.

${ }^{6}$ Two main national sources provide data on foreign student numbers, covering mainly the public sector. The Ministry of Education provides comprehensive annual data on student numbers, broken down by institution type, country of origin, etc. Recently, the Ministry has also started to collect data on student numbers through the Export Education Levy process (Education New Zealand 2004). The second major source of information is immigration data - especially visa statistics provided by the New Zealand Immigration Service. The Ministry's annual data on student numbers is used here to provide an overview of the development and structure of inward student mobility in New Zealand's tertiary sector.
} 
Figure 1. Foreign students in the tertiary education sector, 1989-2003.

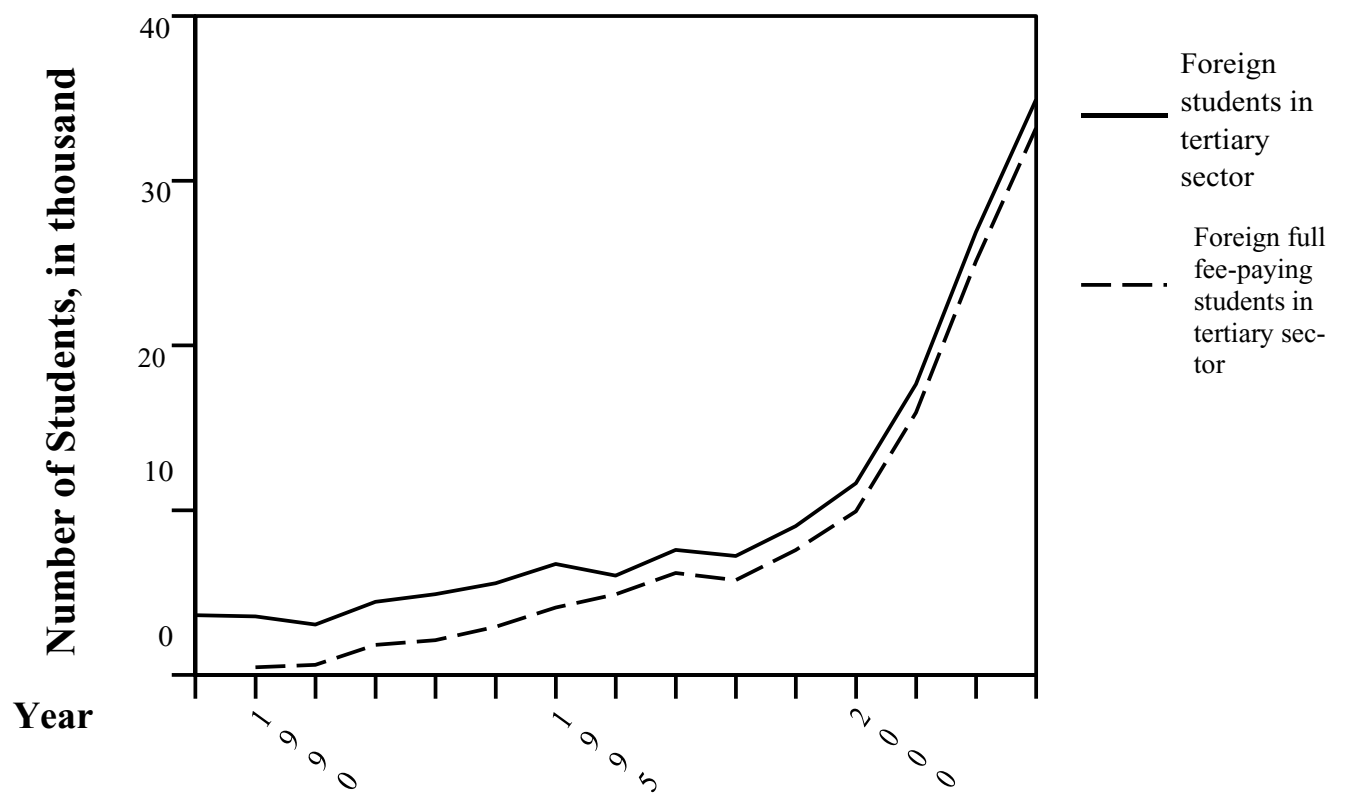

Source: Ministry of Education: Education Statistics of New Zealand, various years.

Note: Data usually refer to students at Universities, Polytechnics, and Colleges of Education. Wananga (Maori education providers) are included for 1995 and from 1998 onwards; private tertiary education providers receiving government subsidies are included from 1999. $(\leftarrow$ p. 10)

The tertiary sector is the area where internationalisation in terms of student mobility has been most intense, not only relative to the other sectors but also to its own size. In 2000, 7191 foreign fee-paying students were studying in the primary and secondary sector, making up $1 \%$ of the total school population, whereas in the public tertiary sector, the number was 11,498 , with foreign fee- paying students representing 3.9\% of the total tertiary sector (Ministry of Education 2001b). The number of foreign students at universities, polytechnics and colleges has seen remarkable growth since the opening in $1989^{7}$. Figure 1 shows this trend and the increasing importance of foreign full fee-paying students among this group. This trend, however, cannot simply be called "privatisation": the direct beneficiaries of this inflow of paying foreign students are mostly public, not private, providers

\footnotetext{
${ }^{7}$ In the primary and secondary sector, the development has been quite similar (Ministry of Education 2001b). King (2003) reports that in recent years the number of foreign fee-paying international students' in New Zealand secondary schools has increased dramatically. For example, since 1998 , the Wellington region has experienced a total growth of $80 \%$. In 2002 , there were already over 15,000 international students in 761 New Zealand schools. Of these, $22 \%$ were enrolled in primary schools and $78 \%$ went to New Zealand secondary and composite schools. This represents a 320\% increase since 1996 (Codd 2003). This increase has in fact led to a situation in which schools are relying on international students funding to meet budget requirements. Longitudinal data for the private tertiary sector is scarce but there is some evidence of growth in student numbers at private training establishments and English language providers in the late 1990s. A survey among the 49 most important English language schools conducted by Statistics New Zealand revealed that in 2000 at least 18,054 foreign students were enrolled in this sector (Ministry of Education 2001b). Purely in terms of numbers, this would make English language schools even more significant than the entire public tertiary sector.
} 
such as the seven state-funded universities. In 2003 , only $20 \%$ of international tertiary students $(7158$ of a total 34,915$)$ went to private tertiary education providers (Ministry of Education 2004a: 105).

The only exception to this continuous growth occurred in 1998, when the Asian economic crisis affected a large part of the market for higher education in general. Most striking, however, is the enormous growth of foreign students in the tertiary sector since the year 2000: numbers of foreign students have more than tripled in the last four years, and most of them are paying full tuition. In 1990, 13\% of all foreign students in the tertiary sector paid full tuition, whereas by 2003 that percentage was already 95.

\section{ASIA AS A MARKET FOR NEW ZEALAND'S EDUCATION INDUSTRY}

Where do these students come from? Table 1 provides a snapshot of the distribution of students according to region of origin for July 2003 . With over $85 \%$ of foreign tertiary students, Asia by far overshadows all the other regions. This is due not only to geographical proximity but also to the high demand of Asian students for international education in general.

Table 2 also depicts student numbers for selected countries over time. China stands out as the main country of origin both within Asia and worldwide. In 2003, 21,974 students $(62.9 \%)$ of all foreign students in the tertiary sector came from China (Ministry of Education 2004a: 104). The Chinese market, however, has only recently become relevant. In the mid-1990s, Chinese students still made up only a small fraction of the international student population, and students from Malaysia - one of New Zealand's traditional partner countries - still represented the most significant market with about one quarter of foreign students. Although since then student numbers for Malaysia have not decreased, the growth of Chinese student numbers has made Malaysia a minor

Table 1. Number of international formal tertiary students by region at 31 July 2003.

\begin{tabular}{lll}
\hline Region of Origin & \multicolumn{1}{c}{ Number of students } & In \% of foreign students \\
\hline Asia & 29,919 & 85.7 \\
Europe & 1836 & 5.3 \\
North America & 1271 & 3.6 \\
Pacific & 1234 & 3.5 \\
Central \& South America & 247 & 0.7 \\
Africa & 236 & 0.7 \\
Middle East & 166 & 0.4 \\
Not stated & 6 & 0.0 \\
TOTAL & 34,915 & 100.0
\end{tabular}

Source: Derived from Ministry of Education (2004a: 103): Education Statistics of New Zealand, Wellington: New Zealand Ministry of Education. $(\leftarrow$ p. 11) 
Table 2. Foreign tertiary students (and \% of total) by country of origin, selected countries.

\begin{tabular}{lllllrlll}
\hline & & $1990^{*}$ & & 1995 & \multicolumn{2}{c}{2000} & & 2003 \\
\hline China & 158 & $(4.4)$ & 79 & $(1.2)$ & 2,294 & $(19.7)$ & 21,974 & $(62.9)$ \\
India & n.a. & (n.a.) & 43 & $(0.6)$ & 249 & $(2.1)$ & 1415 & $(4.1)$ \\
Japan & 27 & $(0.8)$ & 413 & $(6.1)$ & 1,170 & $(10.0)$ & 1054 & $(3.0)$ \\
Korea & 14 & $(0.4)$ & 171 & $(2.5)$ & 863 & $(7.4)$ & 1686 & $(4.8)$ \\
Malaysia & 744 & $(21.0)$ & 1709 & $(25.3)$ & 1,289 & $(11.1)$ & 908 & $(2.6)$ \\
\multicolumn{2}{l}{$\begin{array}{l}\text { Total foreign3538 } \\
\text { students }\end{array}$} & $(100.0)$ & 6742 & $(100.0)$ & 11,638 & $(100.0)$ & 34,915 & $(100.0)$ \\
\end{tabular}

Source: Ministry of Education (various years): Education Statistics of New Zealand, Wellington: New Zealand Ministry of Education; *Universities and Polytechnics.

market within a very short period of time. The comparison of Malaysia and China illustrates the shift from "aid" to "trade": as a Commonwealth member, Malaysia had benefited from the Colombo Plan's education assistance, as Malaysian students were regularly granted scholarships for the New Zealand tertiary sector. From the 1990s, however, the focus has shifted to East Asia, particularly China. In 1999, the New Zealand government lifted quotas for Chinese students that had been imposed for political reasons since 1989 (Asia 2000 Foundation 2003: 11). The enormous growth since that time - as clearly visible in Figure 1 - can be attributed to the end of quotas as well as to the booming Chinese economy and the rising Chinese demand for overseas courses.

In general, both supply and demand factors are behind the remarkable growth of the 1990s. New Zealand's universities charge lower fees than comparable institutions in other English- speaking countries and are geographically closer to Asia, the most important region of origin for international students. Along with increasing demand due to rising incomes in Asian countries and the increased importance of English in the global labour market, this has led to rising student numbers over the last few years (cf. Alvey et al. 1999). A recent report summarises the country's appeal in the international educational market: "New Zealand is an attractive destination for international students because it is English speaking and perceived as clean, green and... safe. New Zealand's education system is considered to be of a high standard, and it is a cheaper destination to complete a bachelor's degree, including course fees and living costs, than Australia, the UK, Canada and the US (Asia 2000 Foundation 2003: 6)".

\section{WHAT IS IT WORTH? FOREIGN EXCHANGE EARNINGS FROM INTER- NATIONAL EDUCATION}

An alternative way of measuring the growth of export education in New Zealand is by looking at the value of foreign exchange earnings generated by foreign students - which can be seen as one of the key benchmarks of the trade-driven 
approach to international education. Obviously, there are a number of measurement problems since students do not only pay tuition fees but contribute to the domestic economy through accommodation and living expenses. Education New Zealand, the industry association, has tried to estimate the overall economic impact of foreign fee-paying students in terms of fees and other expenses. In 2004, this impact was over NZ\$2.1 billion (Education New Zealand 2005). According to their figures, the public tertiary sector - universities, polytechnics and colleges of education - alone accounts for about NZ\$ 1.1 billion in foreign exchange, or $0.8 \%$ of GDP. Even more impressive is the recent growth of the industry that these estimates reveal: In 1997, foreign fee-paying students had spent "only" about NZ\$ 198 million. Thus, there has been an almost six-fold increase within seven years. These estimates, by and $(\leftarrow \mathbf{p}$. 12) large, confirm the trend already evident from the student numbers - a spectacular increase in export education from about the mid-1990s onwards with accelerated growth from 2000, reaching a peak around 2003.

\section{THE ROLE OF NEW ZEALAND'S GOVERNMENT IN FACILITATING THE EDUCATION INDUSTRY}

It is not only economic factors that make New Zealand attractive, however; the country's government drives domestic and international policy to further its education sector. New Zealand actively liberalises education services, particularly in the context of GATS, described above. Apart from its active role at the international level, the government has lowered entry barriers unilaterally (e.g. by relaxing visa regulations) and lessened restrictions on students who are already in New Zealand. English language students who stay for less than a year do not require a visa at all, for instance (Taylor 2000). Students are also allowed to work and earn money. After the Asian financial crisis, the government stepped up its support for the education industry and released a comprehensive Export Education Strategy (Ministry of Education 2001a) which included funding of marketing and capacity-building initiatives in the international education sector.

The government works closely with providers through Education New Zealand, representing all providers. It also attempts to regulate the living conditions for foreign students: in 2001, the mandatory Code of Practice for the Pastoral Care of International Students was introduced to improve standards and provide possibilities of appeal to the International Education Appeal Authority in case of breaches of the code (Lewis 2005) ${ }^{8}$. Revised in 2003, it sets minimum standards of accommodation and access to appeal procedures, particularly for young students in the primary or secondary tier (Ministry of Education 2003). In late 2002, the government introduced a compulsory levy for export education providers to produce additional funding for promotion and communication, industry development, quality assurance, and research (Ministry of Education 2002a). Initially the

${ }^{8}$ A voluntary Code of Practice had already been introduced in 1996 (Lewis 2005). 
Ministry of Education was responsible for the implementation of the work programme associated with the levy. On 1 July 2004, Education New Zealand took over the management responsibility in direct consultation with the Ministry.

\section{EXPORTING NEW ZEALAND EDUCATION TO OTHER COUNTRIES}

Recently, the government has announced further funding "to encourage and support innovation in export education" (Ministry of Education 2004b). As with the earlier levy programme, the new scheme will be administered by the industry itself, through Education New Zealand. Funding of NZ\$ 0.5 million in 2004/2005 and NZ\$ 1 million annually thereafter will be targeted towards offshore education, an area which is still underdeveloped compared to Australia or other main competitors. Offshore education here comprises all types of cross-border education other than student mobility - or, in "GATS language" Modes 1, 3 and 4 (see above). Whereas Australia had more than 1000 offshore programmes in place in 2001 with almost 35,000 students enrolled, New Zealand's share in offshore education is comparatively low. A survey on offshore education conducted in 2001 among all 36 public tertiary institutions in New Zealand revealed a mixed picture: almost one half of the providers offered offshore programmes in 2001, but activities were strongly concentrated within only a few - just three institutions provided 35 of the 63 programmes, and many ran only one offshore programme (Ministry of Education 2002b: 2).

Again, Asia proved to be the most important market. Of the 63 programmes offered in 2001, 26 were delivered through campus-based teaching offshore (Mode 3), 20 were delivered entirely by distance education (Mode 1) and 16 through a combination of campus-based teaching offshore and distance education ${ }^{9}$. According to estimates by the Ministry of Education, $2200(\leftarrow$ p. 13) students were enrolled in offshore programmes. The survey indicated that distance education is an important component of offshore education and is becoming a major international business, expanding together with the growth of "e-commerce"; respondents stated that 12 of the 63 programmes delivered entirely by distance education could potentially be delivered world-wide via the Internet (Ministry of Education 2002b: 4). At present, the pattern of offshore offerings still echoes New Zealand's existing or past international education relationships; 31 of the 63 programmes were delivered in Asia, with Malaysia as the most significant purchaser. However, there are a number of e-learning developments underway in tertiary education, including on-line tutorials, dual-mode campus-based courses and courses that are entirely on the web. At the moment, these initiatives are still primarily domestically focused (Ministry of Education 2002b: 5-6).

\section{NEW ZEALAND IN COMPARATIVE PERSPECTIVE}

Even though New Zealand has been host to a considerable number of international students over the last 15 years, the enrolment of foreign students in absolute

\footnotetext{
${ }^{9}$ Unfortunately, the survey did not cover Mode 4, that is, the cross-border movement of natural persons to provide services abroad, or teacher mobility.
} 
terms in the US, France, Germany, UK, Canada and Australia is still higher. Similarly, New Zealand has been at the forefront of liberalising its education sector and focused on making education an export industry, but it is not the biggest provider of services in this field. In comparison, the key international education providers can still be found in the US, Canada, UK and Australia (OECD 2004). However, in relative terms and compared to other countries New Zealand's development in the education sector is remarkable. The magnitude of this development within the New Zealand education system can be appreciated when the numbers are extrapolated to a population the size of the United Kingdom: New Zealand with a population of 4 million had around 35,000 foreign fee- paying students in 2003. If the UK had a comparable number, with a population of 58 million, it would have over half a million foreign fee-paying students.

Moreover, international students will continue to represent a market which is estimated to be growing at high rates. By the mid-1990s, there were 1.5 million international students world- wide, in the year 2000 estimations were around two million and it is predicted that by 2025 there will be five million students studying at a university of a country other than their home country. Almost half of the international students come from Asian countries and two-thirds of these students are going to an English language destination (Back et al. 1998). The potential for revenues from these international students will foster competition among education systems which follow the trade-driven approach. Being an English-speaking country provides New Zealand with an advantage, but it has to share it with the other main suppliers in the field.

\section{THE EDUCATION INDUSTRY AS A VULNERABLE SECTOR?}

Despite New Zealand's phenomenal rise as a provider of educational services and its government's active role in promoting this sector, there are various problems associated with that development. Most significantly, the education export sector is dependent on international market dynamics just like other export industries, which makes it vulnerable to various external factors not under the control of the New Zealand government. Tougher competition with other providers in the English-speaking world has made it difficult for New Zealand to keep up its numbers of foreign students in recent years. Australia - New Zealand's direct competitor for Asian students - , the UK and Canada are now improving their visa accessibility for foreign students and invest heavily in the promotion of their educational services, particularly in the Chinese market. As a result, New Zealand could be losing its comparative advantage in the field. Moreover, there are new competitors in the education markets, such as Singapore or Hong Kong, which have a $(\leftarrow \mathbf{p . ~ 1 4})$ geographic advantage compared to New Zealand due to their location in the middle of the Asian world. Asian students have fewer adjustment problems in these countries than in New Zealand's "western" atmosphere 
(see Butcher \& McGrath 2004). A rising dollar affects relative tuition rates, and unexpected factors like the outbreak of SARS in 2003 can lead to a sudden decline of foreign student numbers.

Another inherent problem is that since the education sector has become an important industry for New Zealand, the country is gradually more dependent on it. According to estimates, there are about 20,000 jobs in the education sector and expectations are high that large gains will still be possible in the education markets. Local economies gain from foreign students as a side product of educational services: according to an Infometrics study in 2000 , for every dollar directly spent on education and accommodation, approximately 25 additional cents flow through New Zealand's economy (Rotherham 2003). Yet, dependence on a few large markets also involves the potential danger of losses when circumstances change.

In fact, this has been a longstanding issue for New Zealand's export industries in general. As a former colony, the country retained close links with Britain long after having gained independence (1931 Statute of Westminster, ratified in 1947), and even as late as the mid-1960s, more than half of New Zealand's exports went to Britain. Exports were also highly concentrated in terms of their composition, with an extreme dependence on livestock exports, e.g. wool, dairy, meat (Easton 1997). Falling terms of trade for these products in the 1960s and 1970s destabilised the nation's economy. Britain's entry into the European Economic Community in 1973 finally marked the end of the colonial ties that had partially sustained New Zealand. Against this background of experience with external vulnerability, policy-makers and education providers are aware of the risks associated with a strong "modern monoculture" in the education sector. In an attempt to increase market diversification, the government is currently trying to attract more students from other regions, including Central and Eastern Europe and the Middle East. Risk diversification is also one of the main aims cited in the government's Export Education Innovation Programme (Ministry of Education 2004b).

Until now, the education sector has flourished due to a combination of factors, especially New Zealand's image as a clean, green, and safe country that also offers comparatively inexpensive high quality education. Thus, the market is dependent on the perception of it abroad. If this image is tarnished, fewer students will be willing to invest in New Zealand education and will choose a different destination or provider. Moreover, the sector may become less attractive when it is "saturated": If too many students from one country study at the same schools, language improvements and the New Zealand "experience" are not guaranteed because the amount of interaction with native speakers is low, which decreases the genuine nature of study abroad. Some negative repercussions have occurred already; language schools have closed due to lack of students, and there are reports of rising 
anti-Asian sentiments in the population because of the so-called "Asian invasion" of New Zealand business and industry (Rotherham 2003).

\section{CONCLUSION}

In this paper, we have given an overview of New Zealand's recent policy change towards fostering the export of services in education. The spectacular growth of its export education industry - as indicated by student numbers and estimates of foreign exchange earnings - has been accompanied by domestic and international government policies facilitating this trend. New Zealand's governments have been regulating and promoting the education industry, hoping for increasing revenues in education services and stimulating the overall domestic economy. In this vein, New Zealand has proved maybe one of the clearest examples of a "tradedriven" policy in education. However, such a liberalisation of services also raises questions about the fate of state $(\leftarrow \mathbf{p . ~ 1 5})$ intervention in the long term. What role does the state play in the future in a public sector such as education?

Education is an area that many countries have only warily opened up to free trade. Since the nineteenth century, when it was made mandatory and standardised in most industrialised countries, education has been considered a domestic responsibility of the nation-state as regards investment, infrastructure, and employment. Education and educational policy have always been considered classical prerogatives of the modern "intervention state" and denote core elements of its sovereignty and autonomy. Education has been an important means to integrate the nation- state via a common language and an identical historical narrative from its origins (Archer 1979). Moreover, education also became a key tool for improving a state's efficiency, its economic competitiveness and the national income (Coleman 1996). For these reasons, domestic education policy is traditionally publicly funded and often regulated by the state, often intertwined with further qualifications for the labour force in the domestic context. As shown in the example of New Zealand in this paper, steps towards internationalisation and commodification of educational policy can be observed today - but do they come at the expense of a formerly exclusive nation-state domain?

Some observers are indeed arguing in this fashion. The OECD, for instance, appears to expect a weakening of state intervention in the education sector: "If these forms of trade continue to grow, this will not only have important economic repercussions, it could also have profound consequences for education, which has traditionally been organised at a national or sub-national level. It could become harder for national governments to use their own post-secondary systems purely to manage the development of their own labour force and to restrict institutional structures and qualifications systems to a national framework (OECD 2002: 93)".

In contrast to this "pessimistic" outlook, some national governments like New 
Zealand and Australia appear to expect beneficial economic repercussions from the increased trade in education, and thus have been taking a particular active role in promoting export education. What we are observing here - at least in the medium term - is not a diminished role for the state but a higher degree of intervention. These policies may be the sign of a shift to new forms of state intervention in the education sector, from top-down control to a more collaborative role. The terminology of "deregulation" or "privatisation", however, does not capture this new role very well, as the case of New Zealand shows.

The long-term consequences for state intervention are, however, less clear. New Zealand's shift towards exporting education may indicate a long-term shift concerning the goals of education policy in general. Export education is clearly oriented towards generating economic growth and revenue by attracting fee-paying students; integrating the population of the nation-state is not on the agenda in this respect. Moreover, as far as efficiency in this sector is concerned, the focus now is on the side of the providers rather than the students. Instead of aiming at educating the country's own workforce and creating human capital resources, export education is an attempt to generate benefits in a much more direct way, i.e. through income from fees and other expenditures. To what extent this shift may spill over into the realm of domestic education policy remains to be seen and cannot be answered in this article. Further research should take a closer look at the relationship between the trend towards export education and domestic education policies. $(\leftarrow$ p. 16...17)

\section{REFERENCES}

Alvey, J.E., E.J. Duhs, and L.A. Duhs. 1999. New Zealand exports of tertiary education services. In Perspectives on the International Sale of Tertiary Education Services, Issues Paper no. 5, ed. J.E. Alvey, 3-28. Palmerston North: Centre for Public Policy Evaluation, Massey University.

Archer, M.S. 1979. Social origins of educational systems. London and Beverly Hills: Sage.

Asia 2000 Foundation. 2003. The export education industry: Challenges for New Zealand, Asia 2000 Occasional Paper. http: \|www.asia 2000foundation.org. Back, K. D. Davis, \& A. Olsen. 1998. Internationalisation and tertiary education in New Zealand. Wellington: Ministry of Education.

Bok, D. 2003. Universities in the marketplace. The commercialization of higher education. Princeton: Princeton University Press.

Butcher, A. 2003. No place like home? The experiences of South-East Asian international university students in New Zealand and their re-entry into their countries of origin. Albany: Massey University. 
Butcher, A., \& T. McGrath. 2004. International students in New Zealand: Needs and responses, International Education Journal 5, no. 4: 540-551.

Codd, J. 2003. Export education and the commercialisation of public education in New Zealand, New Zealand Annual Review of Education 13: 21-42.

Coleman, J.S. 1996. Bringing new generations into the new social structure. In Society and biography, ed. A. Weymann and W.R. Heinz, 241-258. Weinheim: Deutscher Studien Verlag.

Corbett, A. 2003. Ideas, institutions and policy entrepreneurs: Towards a new history of higher education in the European Community, European Journal of Education 38, no. 3: 315-330.

Easton, B. 1997. In stormy seas: the post-war New Zealand economy. Dunedin: University of Otago Press.

Education New Zealand. 2004. Background briefing to international education statistics. Education New Zealand. http://www.educationnz.org.nz/facts_stats/StatsBackground.pdf.

. 2005. International Education exceeds \$2 billion second year runningthe challenge is keeping it there, Press release 10 April 2005. http://www.educationnz.org.nz/comm_media/media_files/mr10April2005.htm.

Enders, J. 2004 Higher education, internationalisation, and the nation-state: Recent developments and challenges to governance theory. Higher Education 47, 361-382.

Fitzsimons, P., M. Peters, \& P. Roberts. 1999. Economics and the educational policy process in New Zealand, New Zealand Journal of Educational Studies 34 , no. $1: 35-44$.

Harman, G. 2004. New directions in internationalizing higher education: Australia's development as an exporter of higher education services, Higher Education Policy 17, no. 1: 101-120.

Hentschke, G., \& W.G. Tierney. 2005. New players, different game: Understanding the rise of for-profit colleges and universities. Baltimore: Johns Hopkins University Press.

Kahin, B., \& Foray, D. eds. 2006. Advancing knowledge and the knowledge economy. Cambridge, MA: MIT Press.

King, D. 2003. The quiet crisis: International students in New Zealand secondary schools, New Zealand Annual Review of Education 13, 43-62

Levin, H. 2001. Privatizing education. Boulder: Westview. 
Lewis, N. 2005. Code of practice for the pastoral care of international students: Making a globalising industry in New Zealand, Globalisation, Societies and Education 3, no. 1: 5-47.

Martens, K., C. Balzer, R. Sackmann, \& A. Weymann, 2004. Comparing governance of international organisations - The EU, the OECD and educational policy, TransState Working Paper No. 7. Bremen: University of Bremen, http://www.state.uni-bremen.de.

Ministry of Education. Various years. Education statistics of New Zealand. Wellington: Ministry of Education. $(\leftarrow \mathbf{p .} \mathbf{1 8})$

- 2001a. Export education in New Zealand: A strategic approach to developing the sector. Welling- ton: Ministry of Education.

. 2001b. Foreign fee-paying students in New Zealand: Trends. Wellington: Ministry of Education.

. 2002a. Developing export education - the export education industry development fund and levy. Wellington: Ministry of Education.

. 2002b. New Zealand's offshore public tertiary education programmes: Initial stocktake. Wellington: Ministry of Education.

2003. Code of practice for the pastoral care of international students, Revised December 2003. Wellington: Ministry of Education.

. 2004a. Education statistics of New Zealand. Wellington: Ministry of Education.

2004b. Export education innoyation programme: Strategic overview and operational guidelines. Wellington: Ministry of Education.

OECD. 2001. Governance in the $21^{\text {st }}$ Century. Paris: OECD.

_. 2002. Education policy analysis. Paris: OECD.

2004. Internationalisation and trade in higher education. Opportunities and challenges. Paris: OECD.

Oettli, P. 1999. The marketing of higher education in New Zealand and Australia, Paper for the IAUP Conference 1999. International Association of University Presidents http://www.auc.dk/iaup/ 5chap2.htm.

Olssen, M. 2001. The neo-liberal appropriation of tertiary education policy in New Zealand: Accountability, research and academic freedom. Wellington: New Zealand Association for Research in Education.

Peters, M., ed. 2006. Building knowledge cultures: Education and development in the age of knowledge capitalism. Lanham, MD: Rowman \& Littlefield.

Rotherham, F. 2003. Export education - blip or bust?, Unlimited Magazine 1 
September 2003. Sharechat, Copyright: Tarewera Publishing. http://www.sharechat.co.nz/features/unlimited/article.php/ea52f8f5.

Scherrer, C. 2007. GATS - Commodifying education via trade treaties. In New arenas of education governance - the impact of international organizations and markets on educational policymaking, ed. K. Martens, A. Rusconi and K. Leuze, 117-135. Houndmills, Basingstoke: Palgrave Macmillan

Statistics New Zealand 2004 External trade statistics - key points, June 2004. Statistics New Zealand http://www.stats.govt.nz/products-and-services/exttrade-stats/ext-trade-stats-key-points-2004.htm.

Tarling, N. 2004. International students in New Zealand. The making of policy since 1950. Auckland: New Zealand Asia Institute.

Taylor, L. 2000. New Zealand as a provider of transnational education, Higher Education in Europe 25, no. 3, 311-313.

van der Wende, M.C. 2001. Internationalisation policies: About new trends and contrasting paradigms, Higher Education Policy 14, no. 3: 249-259.

Wächter, B. 2004. The Bologna Process: Development and prospects. European Journal of Education 39, no. 3: 265-73.

World Trade Organisation (WTO). 2000. General Agreement on Trade in Services. Geneva: WTO.

- S/CSS/W/93 (2001) Communication from New Zealand. Negotiating proposal for education services, 26 June 2001.

Zürn, M. \& S. Leibfried. 2005. Reconfiguring the national constellation. In: Transformations of the state?, ed. S. Leibfried and M. Zürn, 1-36. Cambridge: Cambridge University Press. (European Review 13, no. 1, special issue). 